\title{
Hyperakut T-hullám, ami „STEMI”
}

\author{
Tomcsányi János dr. \\ Betegápoló Irgalmasrend, Budai Irgalmasrendi Kórház \\ Kardiológia
}

A STEMI definicióját a 2018 évi amerikai kardiológiai társaság (ACC) meghatározása szerint (FUMI negyedik univerzális infarctus definició) a következő 4 pont szerint határozzák meg (1)

- J-pont elevációhoz kötött $S T$ eltérés -inferior $\mathrm{V}_{4-6}$ elvezetésekben $1 \mathrm{~mm}$ felett, $\mathrm{V}_{1-3}$ elvezetésekben $2 \mathrm{~mm}$ felett

- Két, egy régiót reprezentáló elvezetés szükséges

- Lehet olyan EKG is, ami STEMI-nek tekinthető a fenti kritériumok nélkül

- Az egyik ilyen a hyperakut T hullám

\section{Eset}

Egy 55 éves férfi anamnézisében korábbi érdemi betegség nem szerepel. Másfél órás mellkasi fájdalom miatt hívja az ügyeletet. A helyszíni EKG-t az 1. ábra mutatja. A kiérkező orvos bizonytalan volt a diagnózisban és csak az EKG elküldésével derült ki, hogy a betegnek hyperakut T-hulláma van. Az EKG-n, mind az anterior, mind az inferior elvezetésekre kiterjedt a hyperakut T-hullám. Ennek megfelelően az azonnali coronarographia egy, az inferior falra is visszahajló bal elülső leszálló coronariát (wrapped LAD) mutatott subtotális szűkülettel (2. ábra).
Éppen ezért érdemesnek látszik ezt az EKG entitást az irodalom és néhány EKG segítségével körbejárni.

\section{Megbeszélés}

A repolarizációs zavarok számos kérdésére még nincsen biztos válaszunk. Ilyen a hyperakut T-hullám is. Már több mint ötven éve ismert, hogy a magas T-hullám a hyperakut infarctus korai jele (2), de bizonyos esetekben a hyperakut T-hullámot nem kíséri ST-eleváció és a hyperakut T-hullám perzisztál $(3,4)$. Ezen hyperakut T-hullámok jellemzői a következők:

1. Szinte beleolvadnak a QRS terminális részébe

2. Magasak

3. Széles alapúak (szemben a hyperkalaemia keskeny alapú magas T-hullámaival

4. A T-hullámok mindig pozitívak (szemben az agyi katasztrófákat kísérő hasonló, de negatív T-hullámokkal)

Néhány EKG kerül bemutatásra a fenti eset mellett, amikor angiographiával igazolt occlusio illetve subtotalis szűkület állt a repolarizációs zavar hátterében.

Összefoglalva, ha a helyszínen a mellkasi fájdalom mellett ilyen EKG-t látnak akkor kezeljék a beteget úgy, mint ahogyan egy STEMI esetében tennének.

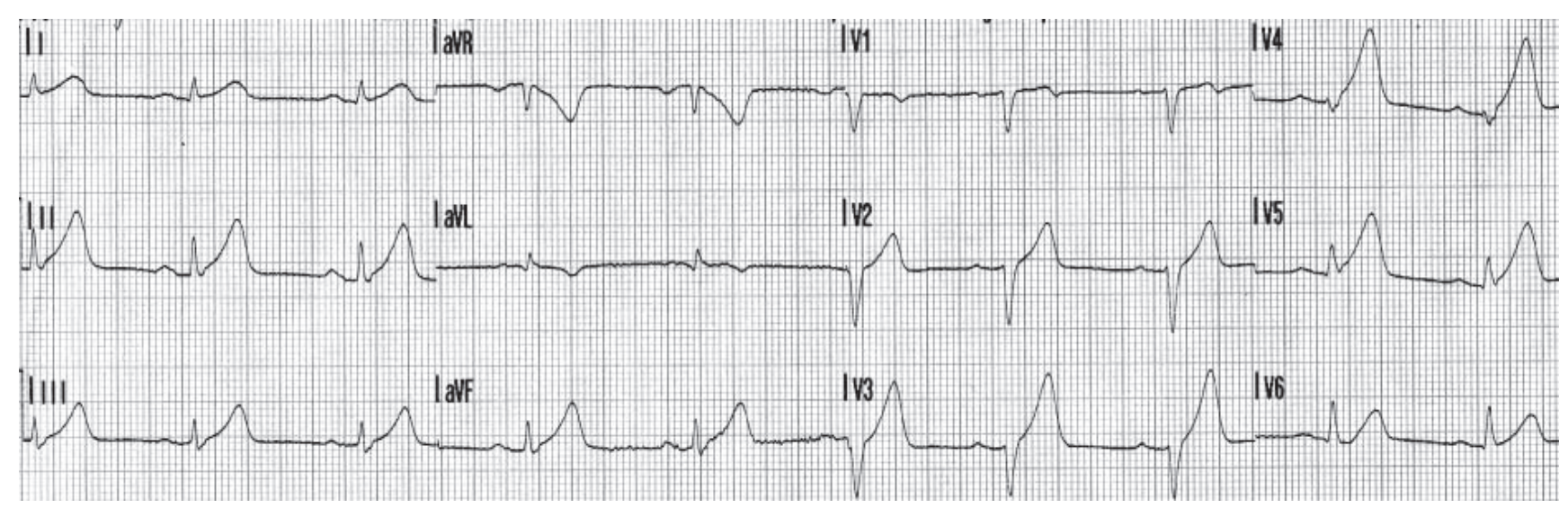

1. ábra. Mellkasi fájdalmat kisérö anterior és inferior hyperakut T-hullámok. 


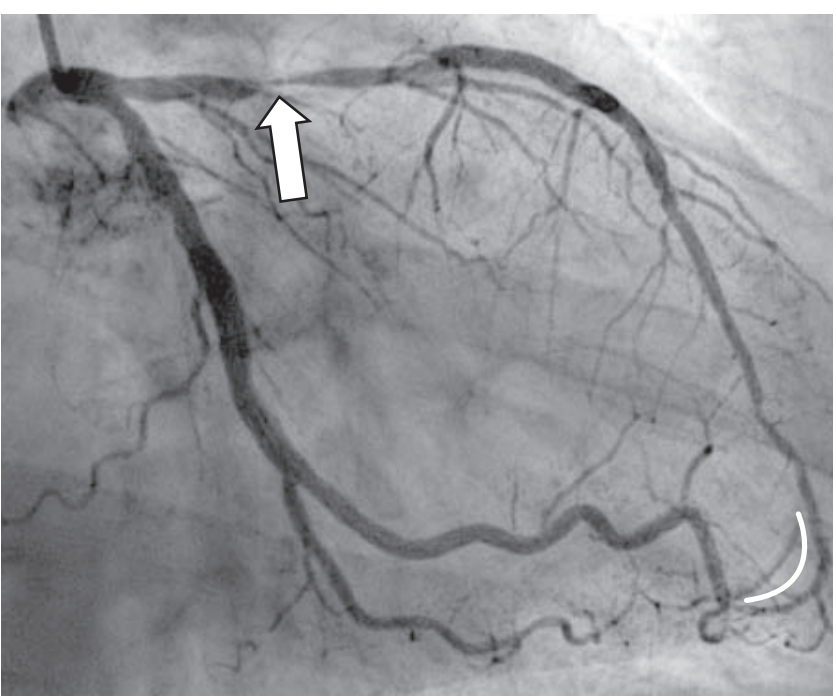

2. ábra. Coronarographia. A bal elülsö leszálló coronaria subtotalis szükülete (nyil). A coronaria az apexen áthajolva az inferior fal egy részét is ellátja (vonal)

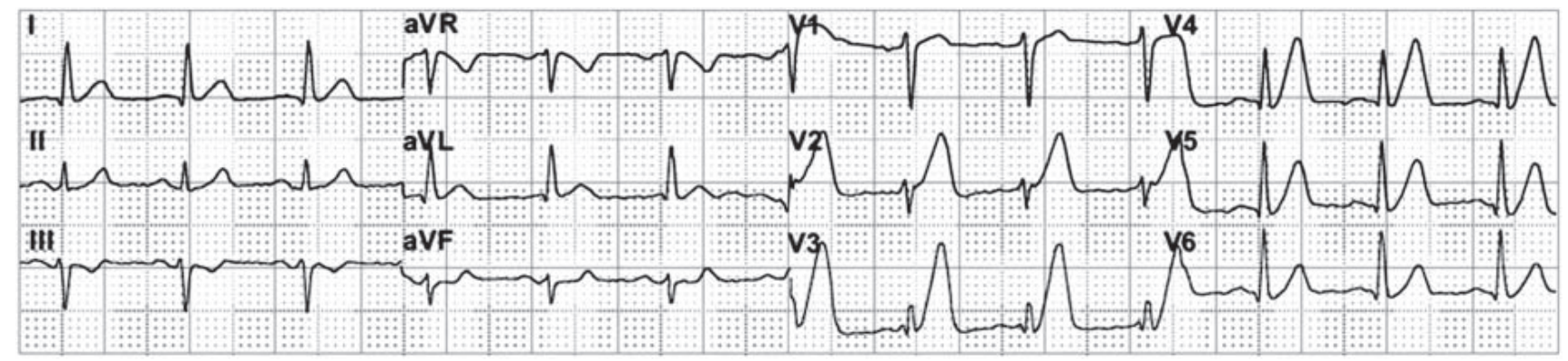

3. ábra. Hyperakut precordiális gigantikusszéles alapú pozitiv T-hullámok, amik beleolvadtak a QRS terminális részébe, így ST-szakasz nem is látható. A T-hullámok perzisztáltak

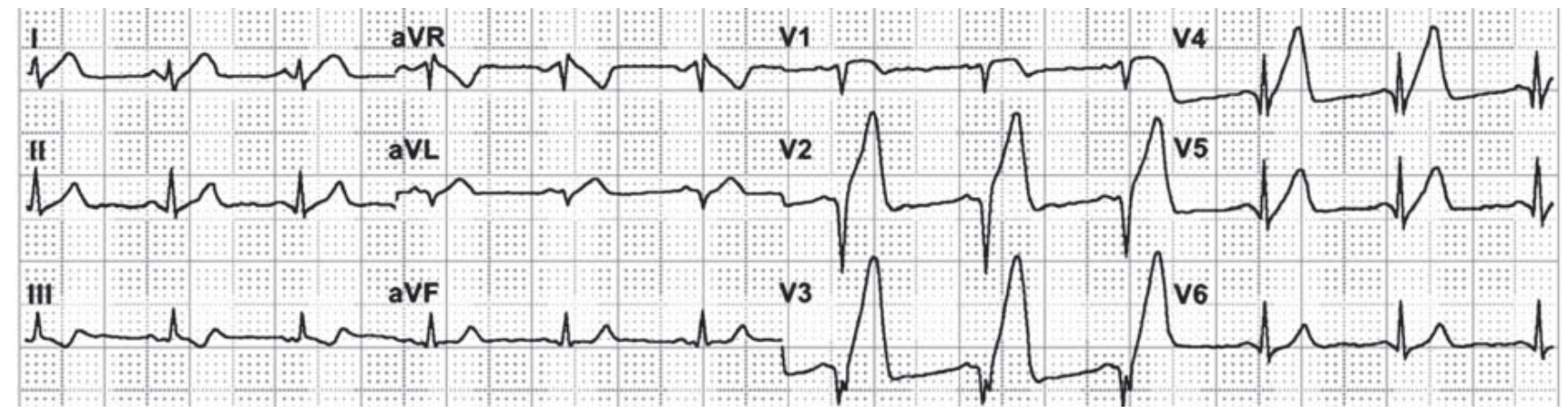

4. ábra. Hyperakut precordialis T-hullámok, korai Q-hullámokkal, amik azonban nem jelentik, hogy nem akut a történés. Ezek a Q-hullámok általában megszünnek, ha korai revascularizáció történik.

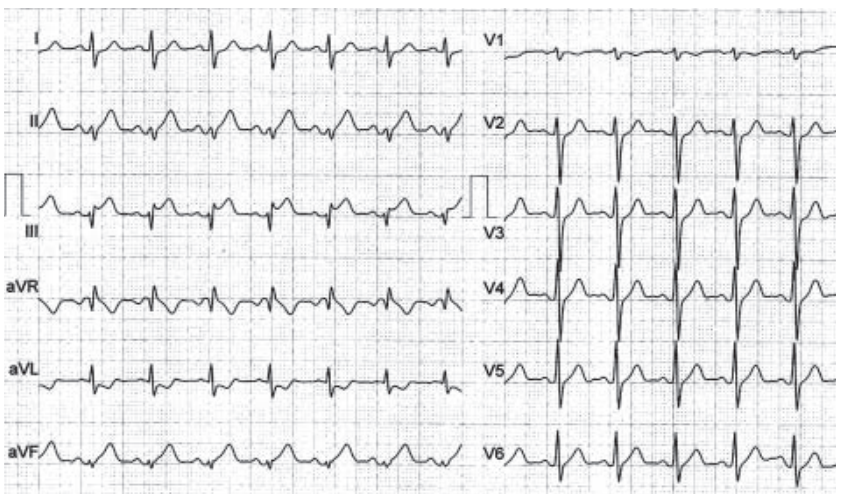

5. ábra. Hyperakut T-hullámok az inferior elvezetésekben. Csak egy elvezetésben van nyereg alakú ST-eleváció (az ST-eleváció forma nem jellemzö STEMI-re), mégis a beteget úgy kell kezelni, mint inferior STEMI-t. 


\section{Irodalom}

1. Thygesen, K., Alpert, JS., Jaffe AS et al. Fourth Universal definition of myocardial infarction (2018). J Am Coll Cardiol. 2018:72(18):2231-64.

2. Dressler, W., Roesler, H.High $\mathrm{T}$ waves int he earliest stage of myocardial infarction. Am Heart J. 1947:34:627-645.
3. Verouden, NJ., Koch, KT., Peters, RJ., et al. Acute coronary syndromes: persistent precordial „hyperacute” T-waves signify proximal left anterior descending artery occlusion. Heart 2009:95:1701-6.

4 Tomcsányi, J., Nényei, Z., Sármán, B., és mtsai. Az akut anterior myocardialis infarctus új EKG-jele. Orv Hetil. 2010:151(10):387-9. 